\title{
Biological Activities of Plants used in Egyptian Ethnopharmacology
}

\author{
Khaled Rashed ${ }^{1}$, Maria Carmo Barreto ${ }^{2 *}$ \\ ${ }^{1}$ Department of Pharmacognosy National Research Centre, 33-El-Bohouth St. (former El Tahrir St.), Dokki, P.O. Box 12622, Giza, Egypt. ${ }^{2}$ Ce3C-Centre \\ for Ecology, Evolution and Environmental Changes / Azorean Biodiversity Group and FCT, Universidade dos Açores, 9501-801 Ponta Delgada, Portugal.
}

\begin{tabular}{l}
\hline ARTICLE INFO \\
\hline Article history: \\
Received on: 02/02/2017 \\
Accepted on: 29/03/2017 \\
Available online: 30/05/2017 \\
\hline Key words: \\
Acetylcholinesterase \\
inhibitors; antioxidants; \\
cytotoxic activity; antitumor \\
agents; polyphenol content.
\end{tabular}

\begin{abstract}
In the present study, six plants traditionally used in Egypt for medical purposes were chosen: Diospyros lotus (Ebenaceae), Bauhinia alba (Fabaceae), Toona ciliata (Meliaceae), Alhagi maurorum (Fabaceae), Terminalia muelleri (Combretaceae) and Pistacia chinensis (Anacardiaceae). Methanol extracts of aerial parts from these plants were tested for biological activities that might corroborate their therapeutic potential. The strongest antioxidant activities, higher than or comparable to the standard compounds used, were presented by Terminalia muelleri and Pistacia chinensis (EC50 of 4.0 and $4.7 \mu \mathrm{g} / \mathrm{mL}$ for DPPH and 7.0 and $49.3 \mu \mathrm{g} / \mathrm{mL}$ for the $\mathrm{FeCl}_{3}$ reduction assay, respectively). These results strongly correlated with the polyphenol content of the extracts. Terminalia muelleri actively inhibited acetylcholinesterase $\left(\mathrm{IC}_{50}=222.9 \mu \mathrm{g} / \mathrm{mL}\right)$, while the other extracts were not active in the range of concentrations tested. Alhagi maurorum presented cytotoxicity against all the cell lines tested, particularly against HeLa tumor cell line $\left(\mathrm{EC}_{50}=16.8 \mu \mathrm{g} / \mathrm{mL}\right)$, with a SI (Selectivity Index) of 3 when compared with the control non tumor cell line.
\end{abstract}

\section{INTRODUCTION}

The medicinal use of plants in Egypt is many thousands of years old, although the best known record, the "Ebers Papyrus", dates from approximately 1500 BC (Borchardt, 2002). Much of this ancient knowledge survived until the present time, especially in rural areas, becoming a valuable contribution to the discovery of new active compounds which may be the scaffold of new drugs. Although several works have recently been published that report studies of this huge potential (Abou Zid et al., 2011; Rashed et al., 2012; El-Seedi et al., 2013; Eissa et al., 2014; Elbanna et al., 2016), it is still a largely unexplored resource worth investigating. Research on the scientific basis of traditional medicine has gained a new impulse, due to the UN World Health Organization recommendations in the recently published document "WHO Traditional Medicine Strategy 2014-2023" (UN World Health Organization, 2013). In the present study, six

\section{* Corresponding Author}

Maria Carmo Barreto, Ce3C-Centre for Ecology, Evolution and Environmental Changes / Azorean Biodiversity Group and FCT, Universidade dos Açores, 9501-801 Ponta Delgada, Portugal.

Email: maria.cr.barreto@uac.pt plants growing in Egypt, traditionally used for medical purposes, were chosen: Diospyros lotus (Ebenaceae), Bauhinia alba (Fabaceae), Toona ciliata (Meliaceae), Alhagi maurorum (Fabaceae), Terminalia muelleri (Combretaceae) and Pistacia chinensis (Anacardiaceae).

Methanol extracts of aerial parts from these plants were prepared, evaporated to dryness and tested for biological activities that might indicate their therapeutic potential.

\section{MATERIALS AND METHODS}

\section{Plant collection and identification}

Aerial parts of Pistacia chinensis and Bauhinia alba leaves were collected from Al-Zohiriya garden, Giza. Diospyros lotus aerial parts, Toona ciliata stems, Alhagi maurorum herb and Terminalia muelleri stems were collected at the Agricultural Research Centre. The plants were identified by Dr. Mohammed ElGebaly, Department of Botany, National Research Centre (NRC) and by Mrs. TereezaLabib consultant of plant taxonomy at the Ministry of Agriculture and director of Orman botanical garden, Giza, Egypt. 


\section{Extraction method}

Air-dried powder of each plant (300 g) was extracted by the maceration method with $70 \%$ methanol (3 L), several times for 48 hours at room temperature $\left(25^{\circ} \mathrm{C}\right)$, until exhaustion. The extract was concentrated and evaporated to dryness under reduced pressure at $40^{\circ} \mathrm{C}$ to give $12.4,8.5,7.8,4.8,10.6$ and 9.7 grams of each plant extract, respectively for Diospyros lotus, Bauhinia alba, Toona ciliata, Alhagi maurorum, Terminalia muelleri and Pistacia chinensis.

\section{Preliminary phytochemical analysis of the extracts}

One $\mathrm{g}$ of each extract was dissolved in methanol, adding a few drops of distilled water for complete solubility, and then the extract was subjected to different phytochemical tests according to that described by Yadav and Agarwala (2011).

Total phenols were determined by the Folin-Ciocalteau method as described by Kuda et al. (2005) and expressed as mg Gallic Acid Equivalents (GAE) per g of dry extract.

\section{Antioxidant and anti-acetylcholinesterasic assays}

The antioxidant activity of the extracts was determined by the 2,2-diphenyl-1-picrylhydrazyl (DPPH) radical scavenging and $\mathrm{FeCl}_{3}$ reduction assays (Barreto et al., 2012) and the in vitro anti-acetylcholinesterasic (anti-AChE) activity was assessed by a modification of the Ellman method (Arruda et al., 2012). Results for the DPPH and anti-AChE assays are expressed as $\mathrm{EC}_{50}$ and $\mathrm{IC}_{50}$, respectively, which is the concentration of extract which caused an effect of $50 \%(50 \%$ DPPH radical scavenging compared with the control without extract or $50 \%$ enzymatic inhibition in the case of anti- AChE activity). In the case of $\mathrm{FeCl} 3$ reduction, $\mathrm{EC}_{50}$ was calculated as the concentration of extract which yielded an Absorbance of 0.5 at $700 \mathrm{~nm}$.

\section{Antibacterial and antitumor activity}

Antibacterial activity against Gram-positive Bacillus subtilis DSM10 and Gram-negative Escherichia coli DSM498 was assessed by the broth microdilution method, as described by De León et al. (2005). Bacteria were added to the microwells containing varying concentrations of extract dissolved in nutrient broth (up to $200 \mu \mathrm{g} / \mathrm{mL}$ ), resulting in a concentration of $5 \times 10^{4}$ $\mathrm{CFU} / \mathrm{mL}$, and the effect of the extracts on bacterial growth, when compared with untreated controls, was assessed after $24 \mathrm{~h}$ at $30^{\circ} \mathrm{C}$ (B. subtilis) or $37^{\circ} \mathrm{C}$ (E. coli) by measuring turbidity at 550 $\mathrm{nm}$. In vitro cytotoxicity against human tumor cell lines HeLa (cervix), MCF7 (breast), A549 (lung) and Vero cell line (nontumor control, Cercopthecus aethiops kidney) was carried out in 96-well microplates according to a previously published method (Moujir et al., 2008).

Briefly, 50000 cells/well were seeded in $100 \mu \mathrm{L}$ DMEM containing $2 \% \mathrm{FBS}$, in the presence of varying concentrations of extract, and cell viability was assessed by the MTT method after $48 \mathrm{~h}$ at $37{ }^{\circ} \mathrm{C}, 5 \% \mathrm{CO}_{2}$ and $98 \%$ humidity. Results are expressed as $\mathrm{EC}_{50}$, which is the concentration of extract which caused $50 \%$ cell cytotoxicity when compared with non-treated control cells.

\section{Statistical analysis}

Results were obtained from at least three independent experiments and were expressed as mean \pm standard deviation. The one-way analysis of variance (ANOVA) was performed followed by Dunnett test, using XLStat. Differences were considered significant at $\mathrm{p}<0.05$. Correlation analysis and linear regression was carried out using Microsoft Excel.

\section{RESULTS}

All the extracts analyzed contained carbohydrates and/or glycosides, condensed and hydrolysable tannins, flavonoids, sterols and/or triterpenes. Alkaloids and/or nitrogenous bases, saponins and coumarins were either absent or present in levels under the detection limit of the qualitative tests used in this work. Concerning polyphenols, levels varied more than ten-fold among the six extracts, between 39.8 and $470.9 \mathrm{GAE} / \mathrm{mg}$ dry extract for A. maurorum and T. muelleri, respectively. The strongest antioxidant activities (Table 1), comparable to quercetin, the standard compound used, were presented by $T$. muelleri and $P$. chinensis. The antioxidant activity of the extracts by the DPPH and $\mathrm{FeCl}_{3}$ reduction methods were correlated $\left(\mathrm{r}^{2}=0.900\right)$.

$T$. muelleri actively inhibited acetylcholinesterase (AChE), while the other extracts were not active in the range of concentrations tested (Table 1). It should be pointed out that the $\mathrm{IC}_{50}$ of $T$. muelleri, although approximately 100-fold the result of berberine, an extremely active AChE inhibitor, is a good result for a whole extract containing a wide array of compounds.

Regarding antimicrobial activity, none of the extracts was active against B. subtilis or $\mathrm{E}$. coli in the range of concentrations tested, i.e., up to $200 \mu \mathrm{g} / \mathrm{mL}$ and in $24 \mathrm{~h}$ of exposure.

Considering that both D. lotus and A. maurorum have been described as being used in traditional medicine to treat tumors in Europe and India (US Department of Agriculture, 2016), the in vitro cytotoxicity of the extracts from these two plants against tumor cell lines was tested (Table 2).

A. maurorum presented cytotoxicity against all the cell lines tested, particularly against HeLa tumor cell line, with $\mathrm{SI}=3$ for this cell line (where SI, Selectivity Index, is the ratio between $\mathrm{EC}_{50}$ values for the Vero reference cell and tumor cell lines, respectively). Although this selectivity was not found for the other cell lines, this is often the case in chemotherapeutic agents, which are often specific for a particular type of cancer. 
Table 1: Antioxidant activities, polyphenol content and anti-AChE activity of the plant extracts.

\begin{tabular}{|c|c|c|c|c|}
\hline Extract / compound & $\begin{array}{c}\text { DPPH } \\
\left(\mathrm{EC}_{50}, \mu \mathrm{g} / \mathrm{mL}\right)\end{array}$ & $\begin{array}{c}\mathrm{FeCl}_{3} \text { reduction } \\
\left(\mathrm{EC}_{50}, \mu \mathrm{g} / \mathrm{mL}\right)\end{array}$ & $\begin{array}{l}\text { Polyphenols } \\
\text { (mg GAE /g) }\end{array}$ & $\begin{array}{c}\text { Anti-AChE } \\
\left(\mathrm{IC}_{50}, \mu \mathrm{g} / \mathrm{mL}\right)\end{array}$ \\
\hline D.lotus & $37.8 \pm 0.66^{\mathrm{a}}$ & $118.5 \pm 0.879^{\mathrm{a}}$ & $235.1 \pm 11.36^{\mathrm{a}}$ & $>250$ \\
\hline B. alba & $75.3 \pm 2.32^{b}$ & $255.6 \pm 1.631^{\mathrm{b}}$ & $385.1 \pm 42.67^{b}$ & $>250$ \\
\hline T. ciliata & $188.9 \pm 8.30^{\mathrm{c}}$ & $356.7 \pm 14.94^{\mathrm{c}}$ & $87.1 \pm 2.34^{\mathrm{c}}$ & $>250$ \\
\hline A. maurorum & $>250$ & $>1000$ & $39.8 \pm 2.14^{\mathrm{d}}$ & $>250$ \\
\hline T. muelleri & $4.0 \pm 0.03^{\mathrm{d}}$ & $7.0 \pm 0.30^{\mathrm{d}}$ & $470.9 \pm 8.74^{\mathrm{e}}$ & $229.9 \pm 19.22^{\mathrm{a}}$ \\
\hline P. chinensis & $4.7 \pm 0.09^{d}$ & $49.3 \pm 0.91^{\mathrm{e}}$ & $285.3 \pm 15.67^{f}$ & $>250$ \\
\hline Quercetin & $4.5 \pm 0.08^{d}$ & $18.4 \pm 0.39^{\mathrm{d}}$ & - & - \\
\hline Berberine & - & - & - & $2.00 \pm 0.22^{\mathrm{b}}$ \\
\hline
\end{tabular}

Results of $n=3$ experiments are presented as mean \pm standard deviation. Values in the same column sharing different letters are significantly different at $\mathrm{p}<0.05$.

GAE, Gallic Acid Equivalents.Quercetin was used as standard antioxidant and berberine as standard AChE inhibitor.

Table 2: In vitro cytotoxicity of D. lotus and A. maurorum extracts (48h exposure) against HeLa, MCF7 and A549 human tumor cell lines; Vero non-tumor cell line was used as control.

\begin{tabular}{|c|c|c|c|c|}
\hline \multirow{3}{*}{$\begin{array}{c}\text { Extract / compound } \\
\text { D. lotus }\end{array}$} & \multicolumn{4}{|c|}{ Cytotoxicity against cell lines $\left(\mathrm{EC}_{50}, \mu \mathrm{g} / \mathrm{mL}\right)$} \\
\hline & HeLa & MCF7 & A549 & Vero \\
\hline & $>200$ & $>200$ & $>200$ & $>200$ \\
\hline A. maurorum & $16.8 \pm 1.83$ & $50.0 \pm 2.76$ & $61.4 \pm 2.60$ & $51.2 \pm 3.98$ \\
\hline Colchicine & $1.7 \pm 0.06$ & $0.02 \pm 0.00$ & $1.4 \pm 0.16$ & $1.4 \pm 0.06$ \\
\hline
\end{tabular}

Results of $n=4$ experiments are presented as mean \pm standard deviation. Colchicine was used as standard chemotherapeutic compound.

\section{DISCUSSION}

The antioxidant activity of the extracts was extremely high, with the exception of A.maurorum, which presented low activity and also low level of polyphenols.

T.muelleri and P.chinensis stand out as being particularly active, both in the DPPH and in the $\mathrm{FeCl}_{3}$ reduction assays. The antioxidant potential of the Terminalia genus corroborates the results of Steekamp et al. (2004), who reported that methanol and water extracts of $T$. sericea had a strong oxidant-scavenging effect in FMLP-stimulated neutrophils, and also of Janporn et al. (2015), who detected high amounts of tocopherol and other antioxidants in the seeds of T. catappa. Pistacia and Diospyros species have also been cited as excellent sources of antioxidants (Krishnaiah et al., 2011). The antioxidant activity may be an important factor in the medicinal properties of these plants, especially when used topically to disinfect and heal wounds. Antioxidant activity could be partially explained by the polyphenol content of the extracts, although the $B$. alba extract, which contained the second highest polyphenol level, corroborating the richness in these compounds reported for other Bauhinia species (Elbanna et al., 2016), was only the fourth strongest antioxidant by both assay methods. It is likely that, in addition to polyphenols, other groups of compounds also contributed to the strong antioxidant activity detected in $P$. chinensis extracts, considering that the level of activity detected was approximately the same as $T$. muelleri, which had 1.65 times more polyphenols, and that the extracts of B. alba and T. ciliata, also very rich in polyphenols, were much weaker antioxidants. The high polyphenol content, almost half of the dry weight in $T$. muelleri, but still extremely high in $B$. alba, P. chinensis and $D$. lotus, is also a positive feature in medicinal plants, since polyphenols are also known as presenting other bioactivities besides antioxidant, such as anticancer and antibacterial ( $\mathrm{Li}$ et al., 2014). Concerning AChE inhibition, the fact that most extracts did not inhibit this enzyme in the range of concentrations tested was not wholly unexpected, considering that the most potent AChE inhibitors known are alkaloids (Barbosa-Filho et al., 2006, Murray et al., 2013), a chemical group which was not detected in these samples. However, phenolic compounds may also present antiAChE activity (Murray et al., 2013), and T. muelleri, which contained the highest amount of polyphenols, was the only extract which presented an inhibition above $50 \%$. The $\mathrm{IC}_{50}$ presented by T. muelleri, $229.9 \mu \mathrm{g} / \mathrm{mL}$, is actually an interesting value for an extract, less than half the $500 \mu \mathrm{g} / \mathrm{mL}$ proposed by Murray et al. (2013) as being the $\mathrm{IC}_{50}$ value above which an extract can be considered as active. Nag and De (2011) also found significant anti-AChE activity in two other Terminalia species, $T$. bellirica and T. chebula, which are used in Ayurvedic medicine as part of a preparation which is supposed to improve mental faculties and to retard aging. Although they used fruit extracts, the high activity found for the same genus corroborates our results, and it should be pointed out that gallic acid and other polyphenols were major components of those extracts, suggesting that this group of compounds was responsible for AChE inhibition. This was experimentally confirmed by the authors, since gallic and ellagic acids strongly inhibited the enzyme (Nag and De, 2011).Actually, polyphenolic AChE inhibitors may be interesting as therapeutic agents, since some polyphenols have been referred as having not only the capacity to inhibit AChE, but also to prevent $\alpha \beta$ peptide aggregation and to disrupt preformed $\alpha \beta$ fibrils (Peckels et al., 2013). Compounds which present this dual effect have a higher probability of being effective in the treatment of Alzheimer's disease, since they raise the level of acetylcholine and at the same time diminish the amyloid beta plaques that interfere with neurotransmission in the brain of patients. Although we did not detect AChE inhibition by A. maurorum, Marashdah and ALHazimi (2010) reported sedation of mice and also blockage of acetylcholine action in perfused frog tissue by an ethanol extract of 
roots from this plant. However, this effect could be caused by an interference with nicotinic receptors and not by inhibition of the enzyme. Also, Benamar et al (2010) report AChE inhibition by leaf aqueous extracts of $P$. atlantica and P. lentiscus, whereas the methanol extract of $P$. chinensis in the present work was not active, but besides being different species, the extraction solvent was not the same.

The fact that we did not detect antimicrobial action against $E$. coli and B. subtilis in plants which are traditionally used to treat bacterial and fungal infections is not surprising, since the maximum concentrations used in the present work $(200 \mathrm{mg} / \mathrm{mL})$ were much lower than the effective concentrations reported by other authors, which are in the order of magnitude of $1 \mathrm{mg} / \mathrm{mL}$ or even $20 \mathrm{mg} / \mathrm{mL}$ (e.g., see Steenkamp et al., 2004, for Terminalia sericea, Bibi et al., 2011, for Pistacia integerrima and Toona ciliata, and Panda et al., 2016, for Bauhinia variegata, several species of Terminalia and of Diospyros). It should also be pointed out that, in medicinal plants used to treat wounds, there are often several other effects acting concomitantly besides antimicrobial, such as anti-inflammatory, immunomodulatory and antioxidant activities, therefore a lower antibacterial activity may contribute to the healing potential of the herb, especially when used in a complex mixture, as is the case of extracts (Dhama et al., 2014).

The high cytotoxic activity of the A. maurorum extract corroborates its traditional use in the treatment of glandular tumors and nasal polyps (U.S. Department of Agriculture, 2016). Our results indicate a higher susceptibility of HeLa cancer cell line, furthermore with a high selectivity index when compared with Vero non tumor cell line. This indicates that further investigation on the active compound responsible for this activity may yield the scaffold for a drug with application against cervix cancer and / or other human carcinomas, presenting lower toxicity to healthy tissue. Although the D. lotus extract was not active against the cell lines used in the present study, a recent study by Rauf et al(2015) isolated dimeric naphthoquinones from the methanol extract of this plant which were quite active as antiproliferative agents against mouse lymphoma cells (L5178), and also against a multidrug resistant cell line (L5178Y MDR).

This result is not surprising, since the cell lines tested in the present work are epithelial adherent cells and therefore quite different from lymphoma cells.

Another aspect which needs to be addressed, especially if the medicinal use of these plants is to be continued, is the safety of their administration. Some studies on thesafety of extracts from these and/or closely related plants have been reported. D. lotus roots and leaf extracts from $D$. kaki did not present toxicity to mice (Uddin et al., 2014; Xieet al., 2015). Although no studies on the safety of $B$. alba were found, B. vahlii leaves are eaten as vegetables in India and used to treat diarrhea and dysentery (Sowndharajan et al., 2013), and studies with mice confirmed their low toxicity (Narayan et al., 2012). Toona ciliata was safe against rats, in doses effective against ulcers (Malairajan et al., 2007). Leaf extracts of Terminalia muelleri did not cause acute toxicity in mice (Fahmy et al., 2015), and extracts of a plant from the same genus, $T$. arjuna, were found to produce no negative effects in long-term clinical trials in humans (Bhawani et al., 2013).P. chinensis bark extract did not cause any significant effect on biochemical and histological parameters in rats (Sattar et al., 2016), whilst its leaves have for a long time been used in tea without any references to negative effects (Bi et al., 2016). Concerning A. maurorum, no toxicity studies have been published so far, although it has also been traditionally used medicinally for many years without reports of negative effects. Although the ethnomedicinal use of the plants reported suggests their toxicity is not very significant, systematic acute and long-term toxicity studies, and also the effects on beneficial microbiota, need to be carried out.

The results obtained in the present work confirm the potential of these medicinal plants, not only as an alternative to conventional treatments by populations with low income, but especially as possible sources of active molecules which may be the scaffolds of future drugs. In this sense, we would like to highlight the interest to carry out further research to isolate and identify the compounds responsible for the activities, in particular the antitumor activity of A. maurorum and the antioxidant activities of $T$. muelleri and $P$. chinensis.

\section{ACKNOWLEDGEMENTS}

Thanks are also due to Dr. Mohammed El-Gebaly, Department of Botany, National Research Centre (NRC) and Mrs. TereezaLabib, consultant of plant taxonomy at the Ministry of Agriculture and director of Orman botanical garden, Giza, Egypt, for plant identification.

Financial support and sponsorship: This work was supported by Fundo Regional da Ciência e Tecnologia (Azores, Portugal) and Fundação para a Ciência e Tecnologia (Portugal) through funding the research unit $\mathrm{Ce} 3 \mathrm{C} / \mathrm{Azores}$ Biodiversity Group through national and regional funds and where applicable co-financed by FEDER, within the PT2020 Partnership Agreement.

Conflict of Interests: The authors' declare no conflict of interest.

\section{REFERENCES}

AbouZid SF, Mohamed AA. Survey on medicinal plants and spices used in Beni-Sueif, Upper Egypt. J Ethnobiol Ethnomed, 2011; 7:18 Arruda M, Viana H, Rainha N, Neng NR, Rosa JS, Nogueira JMF, Barreto MC. Anti-acetylcholinesterase and antioxidant activity of essential oils from Hedychium gardnerianum Sheppard ex KerGawl.Molecules, 2012; 17: 3082-92.

Barbosa-Filho JM, Medeiros KCP, Diniz MF, Batista LM, Athayde-Filho PF, Silva MS, da-Cunha EVL, Silva-Almeida JRG, Quintans-Júnior LJ. Natural products inhibitors of the enzyme acetylcholinesterase.Braz J Pharmacogn, 2006; 16: 258-85.

Barreto MC, ArrudaM, Rego E, Medeiros JS, Rainha N. 2012.Cell-free assays. In: Barreto MC, Simões N, eds. Determination of Biological Activities.A Laboratory Manual. Ponta Delgada: Universidade dos Açores 65-81.

Benamar H, Rached W, Derdour A, Marouf A. Screening of Algerian medicinal plants for acetylcholinesterase inhibitory activity. J BiolSci, 2010; 10:1-9. 
Bhawani G, Kumar A, Murthy KSN, Kumari N, Swami CG. A retrospective study of effect of Terminalia arjuna and evidence based standard therapy on echocardiographic parameters in patients of dilated cardiomyopathy. J Pharm Res 2013; 6:493-498.

Bi W, He C, Ma Y, Shen J, Zhang LH, PengY, Xiao P. Investigation of free aminoacid, total phenolics, antioxidant activity and purine alkaloids to assess the health properties of non-Camellia tea. Acta Pharm Sin B, 2016; 6:170-181.

Bibi Y, Nisa S, Chaudhary FM, Zia M.. Antibacterial activity of some selected medicinal plants of Pakistan. BMC Complement Altern Med, 2011; 11: 52.

Borchardt JK. The beginnings of drug therapy: Ancient mesopotamian medicine.Drug News Perspect, 2002; 15:187-92

De León L, Beltrán B, Moujir L. Antimicrobial activity of 6oxophenolic triterpenoids. Mode of action against Bacillus subtilis.Planta Med, 2005; 71:313-9.

Dhama K, Tiwari R, Chakraborty S, Saminanthan M, Kumar A, Karthik K, Wani MY, Amarpal, Singh SV, Rahal A. Evidence based antibacterial potentials of medicinal plants and herbs countering bacterial pathogens especially in the era of emerging drug resistance: and integrated update. Int J Pharmacol, 2014; 10:1-43.

Eissa TAF, Palomino OM, Carretero ME, Gómez-Serranillos MP. Ethnopharmacological study of medicinal plants used in the treatment of CNS disorders in Sinai Peninsula, Egypt J Ethnopharmacol, 2014; 151:317-32.

Elbanna AH, Mahrous EA, Khaleel AE, El-alfy TS.Chemical investigation of Bauhinia vahlii Wight \& Arnott.leaves grown in Egypt. International Journal of Pharmacy and Pharmaceutical Sciences, 2016; 8: $269-72$.

El-Seedi HR, Burman R, Mansour A, Turki Z, Boulos L, Gullbo J, Göransson U. The traditional medical uses and cytotoxic activities of sixty-one Egyptian plants: Discovery of an active cardiac glycoside from Urginea maritima. J Ethnopharmacol, 2013; 145:746-57.

Fahmy NM, Al-Sayed E, Abdel-Daim MM, Karonen M, Singab AN. Protective effect of Terminalia muelleri against carbon tetrachloride-induced hepato and nephro-toxicity in mice and characterization of its bioactive constituents. Pharm Biol, 2016; 54: 303 313.

JanpornS, Ho C-T, Chavasit V, Pan M-H, Chittrakorn S, Ruttarattanamongkol K, Weerawatanakorn M. Physicochemical properties of Terminalia catappa seed oil as a novel dietary lipid source. J Food Drug Anal, 2015; 23:201-09.

Krishnaiah D, Sarbatly R, Nithyanandam R. A review of the antioxidant potential of medicinal plant species. Food Bioprod Process, $2011 ; 89: 217-33$.

Kuda T, Tsunekawa M, Gotoa H, Araki Y. Antioxidant properties of four edible algae harvested in the Noto Peninsula. Japan J Food Comp Anal, 2005; 18: 625-33.

Li A-N, Li S, Zhang Y-J, Xu X-R, Chen Y-M, Li H-B. Resources and Biological Activities of Natural Polyphenols.Nutrients, 2014; 6:6020-47.

Malairajan P, Gopalakrishnan G, Narasimhan S, Veni KJK, Kavimani S. Anti-ulcer activity of crude alcoholic extract of Toonaciliata Roemer (heart wood). J Ethnopharmacol, 2007; 110: 348-351

Marashdah MS, AL-Hazimi HM. Pharmacological activity of ethanolic extract of Alhagi maurorum roots. Arabian J Chem, 2010; 3:3942.

Moujir L, Seca, AML, Silva AMS, Barreto MC. Cytotoxic activity of diterpenes and extracts of Juniperus brevifolia. Planta Med, 2008; 74:751-3.

Murray AP, FaraoniaMB, Castro MJ, Alza NP, Cavallaro V. Natural AChE Inhibitors from Plants and their Contribution to Alzheimer's Disease Therapy. Curr Neuropharmacol, 2013; 11:388-413.
Nag B, De B. Acetylcholinesterase inhibitory activity of Terminalia chebula, Terminalia bellirica and Emblica officinalis and some phenolic compounds. Int J Pharm PharmSci, 2011; 3:121-4.

Narayan DS, Jagannath PV, Chandra DS. Evaluation of AntiInflammatory, Anti-diabetic activity of Indian Bauhinia vahlii (stembark). Asian Pac J Trop Biomed, 2012; S1382-S1387

Panda SK, Mohanta YK, Padhi L, Park Y-H, Mohanta TP, Bae H. Large scale screening of ethnomedicinal plants for identification of potential antibacterial compounds. Molecules, 2016; 21:293.

Peckels CM, Alexander NA, Wilson GN, Karty JM, Matera KM. Trisubstituted Phenolic Compounds as Inhibitors of Acetylcholinesterase and Amyloid Beta Aggregate Formation. Curr Enzym Inhib, 2013; 9:67-74.

Rashed K, Zhang X-J, Luo M-T, Zheng Y-T. Anti-HIV-1 activity of phenolic compounds isolated from Diospyros lotus fruits. Phytopharmacology, 2012; 3:199-207.

Rauf A, Uddin G, Siddiqui BS, Molnár J, Csonka A, Ahmad B, Szabó D, Farooq U, Khan A. A rare class of new dimeric naphtoquinones from Diospyros lotus have multidrug reversal and antiproliferative effects. Front Pharmacol, 2015; 6: 293.

Sattar S, Khan MR, Shah NA, Noureen F, Naz K. Nephroprotective potential of Pistacia chinensis bark extract against induced toxicity in rats. Nus Biosci, 2016; 8: 192-200.

Sowndhararajan K, Kang SC. Free radical scavenging activity from different extracts of leaves of Bauhinia vahlii Wight \&Arn. Saudi J BiolSci, 2013; 20: 319-325

Steenkamp V, Mathivka E, Gouws MC, van Rensburg CEJ. Studies of antibacterial, antioxidant and fibroblast growth stimulation of wound healing remedies from South Africa. J Ethnopharmacol, 2004; 95:353-7.

Uddin G, RaufaA ,Siddiquic BS, Muhammadb N, Khan A, Shah SUA. Anti-nociceptive, anti-inflammatory and sedative activities of the extracts and chemical constituents of Diospyros lotus L. Phytomedicine, 2014; 21: 954-959.

U.S. Department of Agriculture, Agricultural Research Service.1992-2016.Dr. Duke's Phytochemical and Ethnobotanical Databases. Available at: http://phytochem.nal.usda.gov/ [Accessed 19 July, 2016].

UN World Health Organization, 2013.WHO Traditional Medicine Strategy 2014-2023. ISBN 978924150609 . Available at: http://apps.who.int/iris/bitstream/10665/92455/1/9789241506090_eng.pdf [Accessed 19 July 2016].

Xie C, Xie Z, Xu X, Yang D. Persimmon (Diospyros kaki L.) leaves:A review on traditional uses, phytochemistry and pharmacological properties. J Ethnopharmacol, 2015; 163: 229-240.

Yadav RNS, Agarwala M. Phytochemical analysis of some medicinal plants. J Phytol 2011; 3: 10-4.

How to cite this article:

Rashed K, Barreto MC. Biological Activities of Plants used in Egyptian Ethnopharmacology. J App Pharm Sci, 2017; 7 (05): 046050 . 